\title{
Lung Lesions Induced by Intratracheal Instillation of Nickel Fumes and Nickeloxide Powder in Rats
}

\author{
Tadao TOYA*, Fumio SERITA, Katsuhiko SAWATARI and Kazuo FUKUDA \\ National Institute of Industrial Health, 21-1, Nagao 6-chome, Tama-ku, Kawasaki 214, Japan
}

Received May 13, 1996 and accepted October 7, 1996

\begin{abstract}
Acute and subacute lung toxicity of nickel fumes was examined by single and repeated intratracheal instillation of nickel fumes and $\mathrm{Ni}_{2} \mathrm{O}_{3}$ and $\mathrm{NiO}$ powders in the rat. $\mathrm{LD}_{50}$ of nickel fumes was estimated as $38.2 \mathrm{mg} / \mathrm{kg}$ body weight (b.w.) according to the method of Litchfield and Wilcoxon. Body weight gain was retarded as in the order of a single dose of $13.0 \mathrm{mg} \mathrm{Ni}_{2} \mathrm{O} / \mathrm{kg}>14.3$ $\mathrm{mg}$ nickel fumes/kg $>1.4 \mathrm{mg} \mathrm{Ni} \mathrm{O}_{3} / \mathrm{kg}>13.0 \mathrm{mg} \mathrm{NiO} / \mathrm{kg}$ b.w. compared to controls. The histopathological changes in the lungs of the $14.3 \mathrm{mg}$ nickel fumes/kg-dosed rats were milder than those induced by administration of $13.0 \mathrm{mg} \mathrm{Ni} \mathrm{O}_{3} / \mathrm{kg}$ but severer than those induced by administration of $1.4 \mathrm{mg} \mathrm{Ni} \mathrm{O}_{3} / \mathrm{kg}$ b.w. A single administration of $\mathrm{NiO}$ powder did not produce any histopathological effects on the lungs. The repeated administration of nickel fumes produced persistent edema and proteinosis in the alveoli. The nickel fumes, which were chemically composed of $97 \%$ of $\mathrm{NiO}$ and $3 \%$ of $\mathrm{Ni}_{2} \mathrm{O}_{3}$, were very fine particles about $5-10 \mathrm{~nm}$ in diameter, partly aggregated into larger particles and spherical particles about $0.6 \mu \mathrm{m}$ in diameter. Solubility in distilled water and saline was in the order of nickel fumes $>\mathrm{Ni}_{2} \mathrm{O}_{3}$ powder $\gg \mathrm{NiO}$ powder. It was suggested that a toxic $\mathrm{Ni}_{2} \mathrm{O}_{3}$ component and very fine particles of nickel fumes are involved in the acute lung toxicity of nickel fumes. The epithelial injury induced by reactive oxygen and hydroxy radicals, which would be produced during the process of conversion of $\mathrm{Ni}$ (III) to $\mathrm{Ni}$ (II) and phagocytosis of nickel fumes by macrophages and polymorphonuclear cells, are presumed to be involved in the pathogenesis of nickel fumes-induced lung lesion.
\end{abstract}

Key words: Nickel toxicity, Ni(II)oxide, Ni(III)oxide, Nickel fumes, Dust, Intratracheal instillation, Lung lesions, Histopathological changes

\section{Introduction}

High nickel alloy has been widely used in industry, because of its excellent heat resistance and anticorrosion properties ${ }^{1)}$. Many concerns have been raised concerning the health effects of nickel and its compounds to which workers are exposed in various working environments such as smelting and refining of nickel mat, in nickel foundries, welding, electroplating and $\mathrm{Ni}-\mathrm{Cd}$ batteries. Different forms of nickel such as metallic nickel, $\mathrm{Ni}(\mathrm{III})$ oxide and $\mathrm{Ni}$ (II)oxide, diand tri-valent ions and nickel salts have been reported to

*To whom correspondence should be addressed. adversely affect workers' health through different routes of entry into the body. Occupational inhalation exposure to nickel fumes has been reported to cause lung impairments ${ }^{2)}$ including asthma ${ }^{3)}$, pulmonary fibrosis ${ }^{4)}$ and pneumoconiosis ${ }^{5)}$ as well as carcinogenicity ${ }^{6}$. Inflammatory changes $^{7)}$ and asthma-like lung diseases ${ }^{8)}$ are common characteristics among humans acutely exposed to nickel dust. Acute or subchronic inhalation exposure of experimental animals to nickel dust has been demonstrated to cause histopathological changes in phagocytosis and size distribution of the alveolar macrophages in the rabbit ${ }^{9)}$, an increase in the size of alveolar type II cells and foamy macrophages in the rabbit ${ }^{10)}$, increased lung weight with 
minimal inflammatory reaction in the hamster ${ }^{11)}$, development of pulmonary fibrosis in the mouse ${ }^{12)}$ and alveolar lipoproteinosis in the rat ${ }^{13}$. Inhalation exposure of animals to $\mathrm{Ni}_{2} \mathrm{O}_{3}$ powder caused edema in the alveolar septa and lumen $^{14)}$. Intratracheal instillation of particulate materials allows precise control of the dose to be administered to the animal's lung, leading to precise assessment of the doseresponse or dose-effect relationship for the particulate materials, in comparison to inhalation exposure.

The present study was undertaken to evaluate the lung toxicity of nickel fumes in intratracheal administration in the rat. Nickel fumes which are generated at a high temperature are thought to be composed of various oxides. We also determined the amounts of $\mathrm{NiO}$ and $\mathrm{Ni}_{2} \mathrm{O}_{3}$ in nickel fumes by polarography, in order to find out what kinds of the oxidized components contribute to the lung toxicity of nickel fumes. Both $\mathrm{Ni}_{2} \mathrm{O}_{3}$ and $\mathrm{NiO}$ powders were also administered intratracheally to compare the lung toxicity of nickel fumes and their principal oxidized components. The following items were examined: mortality, growth rates and gross and histopathological changes in the lungs.

\section{Materials and Methods}

\section{Animals}

Male rats of the Sprague-Dawley strain (Crj:CD) were purchased from Charles River Japan at the age of 4 weeks and housed in wire-meshed cages (5 rats/cage) in an animal colony. The animal room was maintained at a temperature of $24 \pm 1{ }^{\circ} \mathrm{C}$, a relative humidity of $55 \pm 5 \%$ and an automatic lighting schedule of a 12-hr light (8:00-20:00)/12-hr dark (20:00-8:00) cycle. The rats were allowed free access to autoclaved food pellets and tap water sterilized by ultraviolet irradiation.

\section{Preparation of nickel fumes and nickel oxide powders instilled}

Three kinds of particulate materials, nickel fumes, $\mathrm{Ni}_{2} \mathrm{O}_{3}$ and $\mathrm{NiO}$ powders were used in the present study. Nickel fumes was generated by feeding metallic nickel powder (56F, Nickel Powder Metco, USA) into a plasma flame metal sprayer ${ }^{15,16)}$ with which molten nickel metal was released into an aerosol chamber. The fumes generated were collected on the surface of glass beads by means of a granular bed type fume collector. The nickel fumes collected were separated from the glass beads with a 250 mesh sieve. $\mathrm{Ni}_{2} \mathrm{O}_{3}$ and $\mathrm{NiO}$ powders were purchased from Kosou Chemicals (G2B081, G3H22906, respectively, Japan) and their nominal particle sizes were reported as $2.0 \mu \mathrm{m} \pm 1.69$ (geometric mean \pm geometric $\mathrm{SD}$ ) and $2.2 \mu \mathrm{m} \pm 1.68$, respectively, according to the manufacturer. Each type of nickel fumes, $\mathrm{Ni}_{2} \mathrm{O}_{3}$ and $\mathrm{NiO}$ powders, was dispersed in a sterilized physiological saline, and sonicated for $15 \mathrm{~min}$ immediately before intratracheal instillation.

Characterization of the nickel fumes and nickel oxide powders

Size distributions of nickel fumes, $\mathrm{Ni}_{2} \mathrm{O}_{3}$ and $\mathrm{NiO}$ powders, were determined with a transmission electron microscope (H-8000, Hitachi Co., Japan). The particulates were dispersed in distilled water and sonicated for $30 \mathrm{sec}$. The particulate suspensions of $1 \mu \mathrm{l}$ each were placed on an EM grid with carbon enforced collodion film. Transmission electron microscope (TEM) observations were performed to measure particulate sizes at various magnifications. For fine particles, the photograph was taken at a magnitude of $\times 100,000$, and for agglomerated particles, at $\times 600$. These TEM negative films were optically enlarged 5-10 times on the prints.

Amounts of $\mathrm{NiO}$ and $\mathrm{Ni}_{2} \mathrm{O}_{3}$ components in nickel fumes were determined with a PAR174A polarographic analyzer equipped with a model 303 dropping mercury electrode (Princeton Applied Research Co., U.S.A.). Polarographic analysis was done by the method previously reported ${ }^{17)}$.

\section{Administration of fumes and powder}

Each 8-week-old rat was anesthetized with ether. Under direct observation of the larynx with a dissecting microscope, the rat received intratracheal intubation to the region near the carina. The particulate suspension of $0.5 \mathrm{ml}$ followed by injection of $0.5 \mathrm{ml}$ expired gas was instilled out into the lungs in the inspiration phase. A different group of rats received intratracheal instillation of the vehicle solution in the same manner and served as a control. To determine the $\mathrm{LD}_{50}$ of the nickel fumes, amounts of particulates ranging between 0.5 and $120 \mathrm{mg}$ per animal were administered into the trachea. The doses of nickel fumes and nickeloxide powder and the numbers of rats used are shown in Table 1. A single instillation of $3.8 \mathrm{mg}$ nickel fumes $/ \mathrm{kg}$ was equivalent to the minimum lethal dose which was determined by the dose-lethality curve for nickel fumes.

In order to find out what kinds of the oxidized components contribute to the lung toxicity of nickel fumes, other groups of rats were given intratracheal instillation of $\mathrm{Ni}_{2} \mathrm{O}_{3}$ powder suspension at single doses of 1.4 and $13.0 \mathrm{mg} / \mathrm{kg}$ b.w. and $\mathrm{NiO}$ powder suspension at a single dose of $13.0 \mathrm{mg} / \mathrm{kg}$ b.w. 
Table 1. Amounts of nickel fumes and nickeloxide powder instilled intratracheally into the lungs, and the number of rats used

\begin{tabular}{lccc}
\hline Administrations & Substances & Doses $(\mathrm{mg} / \mathrm{kg})$ & No. of rats used \\
\hline \multirow{4}{*}{ Single instillation } & Nickel Fume & 3.8 & 30 \\
& & 14.3 & 25 \\
& $\mathrm{Ni}_{2} \mathrm{O}_{3}$ & 1.4 & 27 \\
& & 13.0 & 23 \\
& $\mathrm{NiO}$ & 13.0 & 23 \\
& $\mathrm{Control}$ & 0 & 15 \\
\hline \multirow{3}{*}{ Repeated instillations } & & $5.9 \times 4$ & 31 \\
& Nickel Fumes & total 20.0 & \\
& & (once every two weeks) & \\
& Control & 0 & 15 \\
\hline
\end{tabular}

\section{Histopathological preparations of the lung}

Five rats each were sacrificed for histopathological examination of the lungs and major visceral organs on Day 4 after instillation and Weeks 1, 2, 4 and 8 after the final instillation. Each animal was anesthetized with pentobarbital sodium $(60 \mathrm{mg} / \mathrm{kg}$, i.p.) and then bled to death by cutting the abdominal aorta. Before open thoracotomy, $1.5 \mathrm{ml}$ of $10 \%$ phosphate-buffered formalin solution were instilled into the lung, and then the trachea was ligated. After gross observation, the lungs and major visceral organs were fixed in the same fixative for 2-3 days. About $3 \mathrm{~mm}$ thick slices of the right lung were cut along the longitudinal axis of the main bronchus and other slices were cut perpendicular to the bronchial axis. These slices were dehydrated and embedded in paraffin. The paraffin sections, $5 \mu \mathrm{m}$ thick, were stained with hematoxylin and eosin (H \& E). Masson Trichrome stain and Periodic Acid Schiff stain were also used when needed.

\section{Histopathological evaluation of the affected lungs}

Histopathological changes in the lungs of the rats to which nickel fumes, $\mathrm{Ni}_{2} \mathrm{O}_{3}$ and $\mathrm{NiO}$ powders were administered were examined under a microscope to check for the following 9 items: 1) Cloudy swelling and mucoid degeneration, 2) Regeneration of the broncho-bronchiolar epithelium, 3) Reactive hyperplasia, 4) Exudation and accumulation of inflammatory cells and mobilization and destruction of macrophages, 5) Foreign-body granuloma, 6) Increased number and swelling of fibroblast cells, 7) thickening of the alveolar wall and ducts due to increased collagenous materials, 8) Proteinosis and 9) Edema. Each of the above mentioned histopathological changes was scored on a scale of increasing severity from 0 to 4: 0 indicates no change or the same changes as those observed in the lungs of control rats given physiological saline. 1 indicates very slight or sporadic changes observed in a small, limited area. 2 indicates slight but unambiguous changes observed in the same area. 3 indicates moderate changes in the lesion restricted to an area smaller than $1 / 3$ of the total area of the lobe. 4 indicates marked changes in a lung lesion that extended over an area larger than $1 / 3$ of the lobe.

\section{Solubility test}

Ten milligrams of each of the three particulates, nickel fumes, $\mathrm{Ni}_{2} \mathrm{O}_{3}$ and $\mathrm{NiO}$ powders, were suspended in distilled water or saline of $10 \mathrm{ml}$, and then sonicated for $15 \mathrm{~min}$. After filtration of the suspension with a millipore filter $(0.3$ $\mu \mathrm{m}$ in pore diameter), the amount of nickel dissolved in water or saline was determined with a flameless atomic absorption spectrometer (Perkin Elmer Model Zeeman/5000 System, U.S.A.).

\section{Results}

Characterization of nickel fumes and nickel oxide powders

Nickel fumes were composed mainly of very fine particles about $10 \mathrm{~nm}$ in diameter, partially agglomerated particles and spherical particles about $0.6 \pm 2.1 \mu \mathrm{m}$ (geometric mean \pm geometric $\mathrm{SD}$ ) in diameter. $\mathrm{NiO}$ powder particles were $1.7 \pm 2.1 \mu \mathrm{m}$ in diameter. The size distribution of $\mathrm{Ni}_{2} \mathrm{O}_{3}$ powder was similar to that of fine particles in nickel fumes.

The polarographic determination revealed that nickel fumes were chemically composed of two oxidized forms; $1.2-3.2 \%$ of $\mathrm{Ni}_{2} \mathrm{O}_{3}$ and $98.8-96.8 \%$ of $\mathrm{NiO}$.

\section{Mortality}

Table 2 shows the relationship between a single dose of 
Table 2. Mortality after intratracheal instillation of nickel fumes into Sprague-Dawley rats at different doses

\begin{tabular}{llrrrrr}
\hline Dose (mg/rat) & 0.5 & 2 & 8 & 30 & 60 & 120 \\
No. of rats instilled & 7 & 7 & 7 & 9 & 7 & 6 \\
No. of rats dead & 0 & 1 & 3 & 7 & 7 & 6 \\
$\begin{array}{l}\text { Mortality \% } \\
\begin{array}{l}\text { Days survived after } \\
\text { the instillation }\end{array}\end{array}$ & 0 & 14 & 43 & 78 & 100 & 100 \\
\hline
\end{tabular}

2*: Six out of 7 died on day 2 , and another died on day 9 .

nickel fumes intratracheally instilled and the mortality of the rats. Death due to toxic insult was observed during the 10 days after the intratracheal instillation. Death was caused by respiratory failure resulting from edema, hemorrhage and desquamation of the bronchiolar epithelium. A value of $\mathrm{LD}_{50}$ for nickel fumes was estimated to be $38.2 \mathrm{mg}$ nickel fumes/ $\mathrm{kg}$ b.w. according to the method of Litchfield and Wilcoxon ${ }^{18)}$. The instillation of nickel fumes at single doses of 3.8 and $14.3 \mathrm{mg} / \mathrm{kg}$ b.w., which corresponded to $\mathrm{LD}_{6}$ and $\mathrm{LD}_{27}$, respectively, actually caused $0 \%$ and $4 \%$ mortality, respectively. No death was observed during the 8 weeks after repeated instillations of nickel fumes at doses of 5.9 $\mathrm{mg} / \mathrm{kg}$ once every 2 weeks (a total dose of $20 \mathrm{mg} / \mathrm{kg} \mathrm{b.w.).}$ Sixty percent of the 23 rats instilled with a single dose of $13.0 \mathrm{mg} \mathrm{Ni}_{2} \mathrm{O}_{3} / \mathrm{kg}$ died within 5 days and their death was caused by edema. A single instillation of either $1.4 \mathrm{mg} \mathrm{Ni}_{2} \mathrm{O}_{3} /$ $\mathrm{kg}$ or $13.0 \mathrm{mg} \mathrm{NiO} / \mathrm{kg}$ b.w. caused no death.

\section{Growth rate}

Figure 1 shows the growth rates of the rats given single doses of 3.8 and $14.3 \mathrm{mg}$ nickel fumes $/ \mathrm{kg}, 13.0 \mathrm{mg}$ and 1.4 $\mathrm{mg} \mathrm{Ni}{ }_{2} \mathrm{O}_{3} / \mathrm{kg}$ and $13.0 \mathrm{mg} \mathrm{NiO} / \mathrm{kg}$ b.w., in comparison with the growth rate of the rats given saline as the control. The administration of $14.3 \mathrm{mg}$ nickel fumes/ $\mathrm{kg}$ decreased the body weight for the first several days and the growth rate tended to be retarded thereafter, but there was no essential difference between the $3.8 \mathrm{mg}$ nickel fumes/kg-instilled rats and the control in body weight. The rats given a single dose of $13.0 \mathrm{mg} \mathrm{Ni}{ }_{2} \mathrm{O}_{3} / \mathrm{kg}$ exhibited a pronounced decrease in body weight throughout the observation period of 7 days. Retardation of the growth rate of the $1.4 \mathrm{mg} \mathrm{Ni}_{2} \mathrm{O}_{3} / \mathrm{kg}$-instilled rats was similar to that of the $14.3 \mathrm{mg}$ nickel fumes $/ \mathrm{kg}$ instilled rats. A single instillation of $13.0 \mathrm{mg} \mathrm{NiO} / \mathrm{kg}$ did not produce any decrease in the growth rate throughout the observation period of 15 days. As shown in Figure 2, there was a slight but insignificant difference in the growth rate between the rats given repeated doses of $5.9 \mathrm{mg}$ nickel fumes/

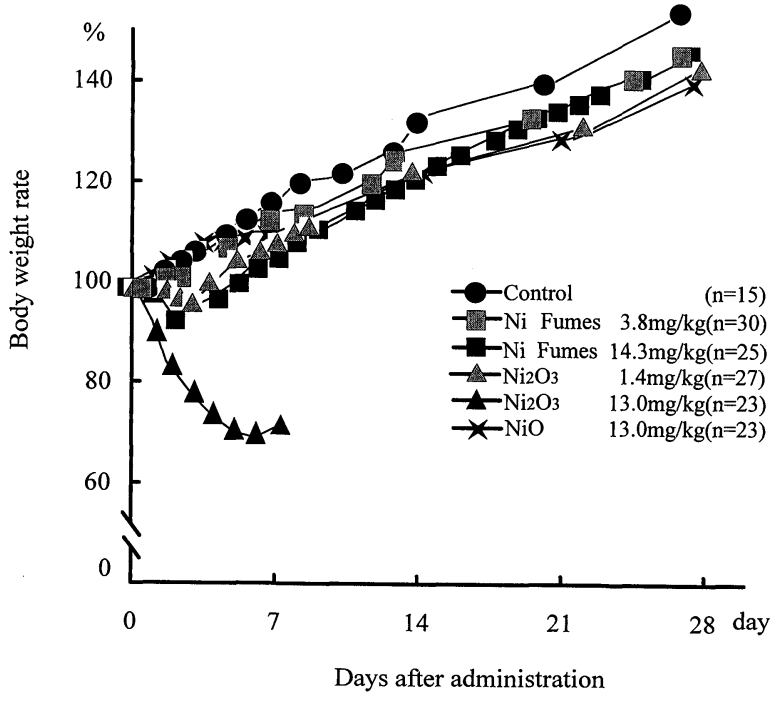

Fig. 1. Time course changes in growth rates of the rats after single intratracheal instillations of nickel fumes, $\mathrm{Ni}_{2} \mathrm{O}_{3}$ and $\mathrm{NiO}$ powders or physiological saline as the control

The growth rate was expressed as body weight after the instillation as a percentage of that before. The number of rats in each group is indicated in parenthesis.

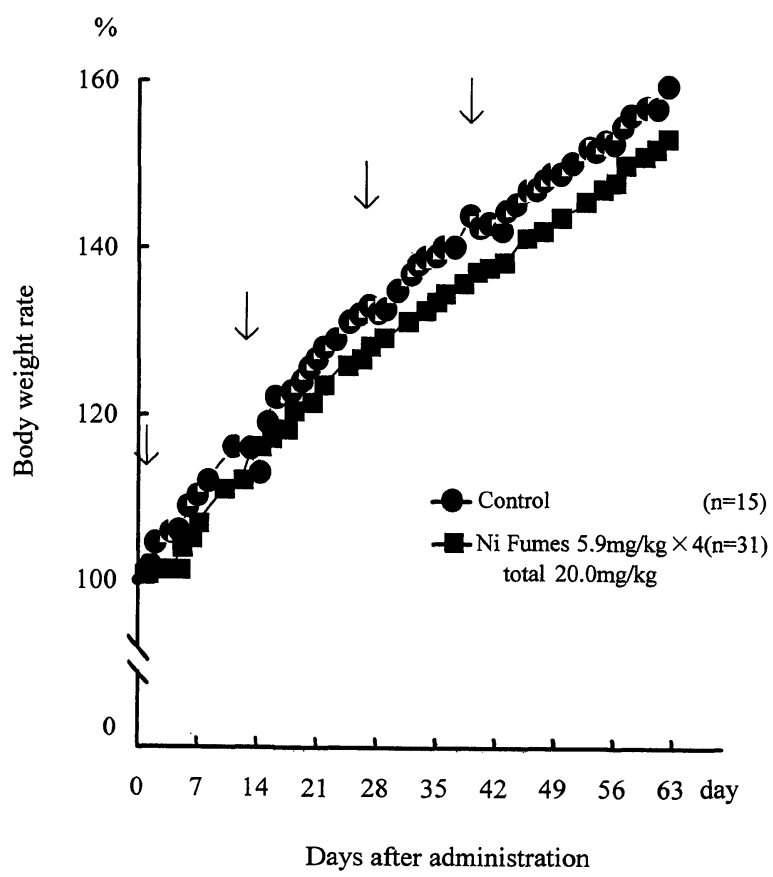

Fig. 2. Time course changes in the growth rates of rats after repeated intratracheal instillations of nickel fumes or physiological saline as the control

The growth rate was expressed as body weight after the instillation as a percentage of that before. The number of rats in each group is indicated in the parenthesis. The arrows indicate the days when the rats received the instillations. 
$\mathrm{kg}$ and the control.

\section{Gross findings}

On Days 4 to 7 after the instillation at a single dose of $14.3 \mathrm{mg}$ nickel fumes $/ \mathrm{kg}$, the lungs of the rats were characterized by brown induration of the pulmonary hilus. These lesions disappeared by Weeks 4 to 8 . The rats given a single dose of $3.8 \mathrm{mg}$ nickel fumes $/ \mathrm{kg}$ exhibited slighter changes and their lung lesions disappeared after Week 2. Repeated instillations of nickel fumes produced the same degree of lung lesions as observed in the $14.3 \mathrm{mg} / \mathrm{kg}$ administered rats, but these lung lesions persisted for the first 4 weeks after the final administration and tended to be recovered afterward.

The lungs of the $13.0 \mathrm{mg} \mathrm{Ni}_{2} \mathrm{O}_{3} / \mathrm{kg}$-administered rats which died within 5 days were characterized by consolidation, red coloration, diffuse atelectasis and exudation of serous liquids into the thoracic cavity. The lesions induced by administration of $13.0 \mathrm{mg} \mathrm{Ni}_{2} \mathrm{O}_{3} / \mathrm{kg}$ were far severer than those induced by $14.3 \mathrm{mg}$ nickel fumes $/ \mathrm{kg}$-administration. The surviving rats that had received $13.0 \mathrm{mg} \mathrm{Ni} \mathrm{O}_{3} / \mathrm{kg}$ exhibited marked diffuse hemorrhage and crater-like induration on the surface of the lobes. The $1.4 \mathrm{mg} \mathrm{Ni}_{2} \mathrm{O}_{3} /$ $\mathrm{kg}$-administered rats exhibited hemorrhagic patches on the entire lobes and edematous swelling on Days 4 to 7 . These lesions became slighter on Weeks 4 to 8 than on Days 4 to 7. There were no observable changes in the lungs of the rats given $13.0 \mathrm{mg} \mathrm{NiO} / \mathrm{kg}$ except for slightly red coloration over the lobes.

\section{Histopathological examinations of the lungs}

As shown in the microphotographs (Fig. 3), the lung lesions induced by the single instillation of nickel fumes were characterized by goblet cell hyperplasia, perivascular inflammatory cells and edema in the alveolar space (in A), whereas repeated instillations produced a secretion of proteinaceous materials in the alveolar space (in B). $\mathrm{Ni}_{2} \mathrm{O}_{3}$ administration produced goblet cell hyperplasia, focal granuloma, inflammatory cells in the alveolar space and thickening of the alveolar wall (in C), but $\mathrm{NiO}$ did not produce any apparent histopathological change in the lungs (in $\mathrm{D}$ ).

Severity scores for the histopathological changes in the lungs of the rats given nickel fumes, $\mathrm{Ni}_{2} \mathrm{O}_{3}$ and $\mathrm{NiO}$ powders are shown in Tables 3 and 4. The single and repeated instillations of nickel fumes were found to produce the following characteristic changes with varying degree of severity (Table 3 ): Hypersecretion and reactive hyperplasia of the broncho-bronchiolar epithelium as well as the alveolus was observed on Days 4 to 7 after a single dose of $14.3 \mathrm{mg} / \mathrm{kg}$. Marked mobilization of the macrophages into the alveoli, the destruction of macrophages, granuloma and thickened alveolar septa resulting from infiltration of inflammatory cells were also observed. After 4 to 8 weeks, the lesions became slighter, but the number of foamy, particulate-laden macrophages increased and mild fibrosis developed in the alveolar duct. In comparison to the above mentioned histopathological changes induced by the administration of $14.3 \mathrm{mg} / \mathrm{kg}$, a single instillation of 3.8 $\mathrm{mg}$ nickel fumes/kg produced slight changes by Days 4 to 7 and both abundant debris of the dead macrophages and mobilization of the foamy macrophages into the alveoli during Weeks 4 to 8 . The repeated administration of nickel fumes at a total dose of $20 \mathrm{mg} / \mathrm{kg}$ caused proteinosis, edema and slight fibrosis in the alveoli by Days 4 to 7 after the final instillation. By Weeks 4 to 8 , the proteinosis and fibrosis were observed in addition to the development of the above mentioned histopathological changes in the macrophages.

The single instillations of 13.0 and $1.4 \mathrm{mg} \mathrm{Ni}_{2} \mathrm{O}_{3} / \mathrm{kg}$ and $13.0 \mathrm{mg} \mathrm{NiO} / \mathrm{kg}$ were characterized by the following histopathological changes with various degrees of severity (Table 4): The instillation of $13.0 \mathrm{mg} \mathrm{Ni} \mathrm{O}_{3} / \mathrm{kg}$ produced edema in the alveolar spaces and around the vessels, necrosis, desquamation and regeneration of the bronchobronchiolar epithelium and an early stage of thickening in the alveolar ducts and wall. The lesions induced by the $1.4 \mathrm{mg} \mathrm{Ni}_{2} \mathrm{O}_{3} / \mathrm{kg}$ administration were far slighter than those induced by the $13.0 \mathrm{mg} / \mathrm{kg}$ administration. The changes in of the lungs observed in Weeks 4 to 8 after the $1.4 \mathrm{mg}$ $\mathrm{Ni}_{2} \mathrm{O}_{3} / \mathrm{kg}$ administration were characterized by mobilization of the alveolar macrophages, an increase in the number of foamy cells, proteinosis in the alveoli and fibrosis in the alveolar ducts and wall. The instillation of $13.0 \mathrm{mg} \mathrm{NiO} /$ $\mathrm{kg}$ did not produce any histopathological changes except a small number of foamy macrophage cells containing $\mathrm{NiO}$ particles and the sporadic appearance of granuloma surrounded by bronchiolar epithelia in 3 out of the 24 instilled rats.

\section{Solubility}

Nickel fumes were solubilized into distilled water and saline by 1.8 and $2.1 \mathrm{wt} \%$, respectively. $\mathrm{Ni}_{2} \mathrm{O}_{3}$ powder was dissolved into distilled water and saline by 1.2 and $0.35 \mathrm{wt}$ $\%$, respectively, but $\mathrm{NiO}$ powder was not dissolved in either of the two liquids. 

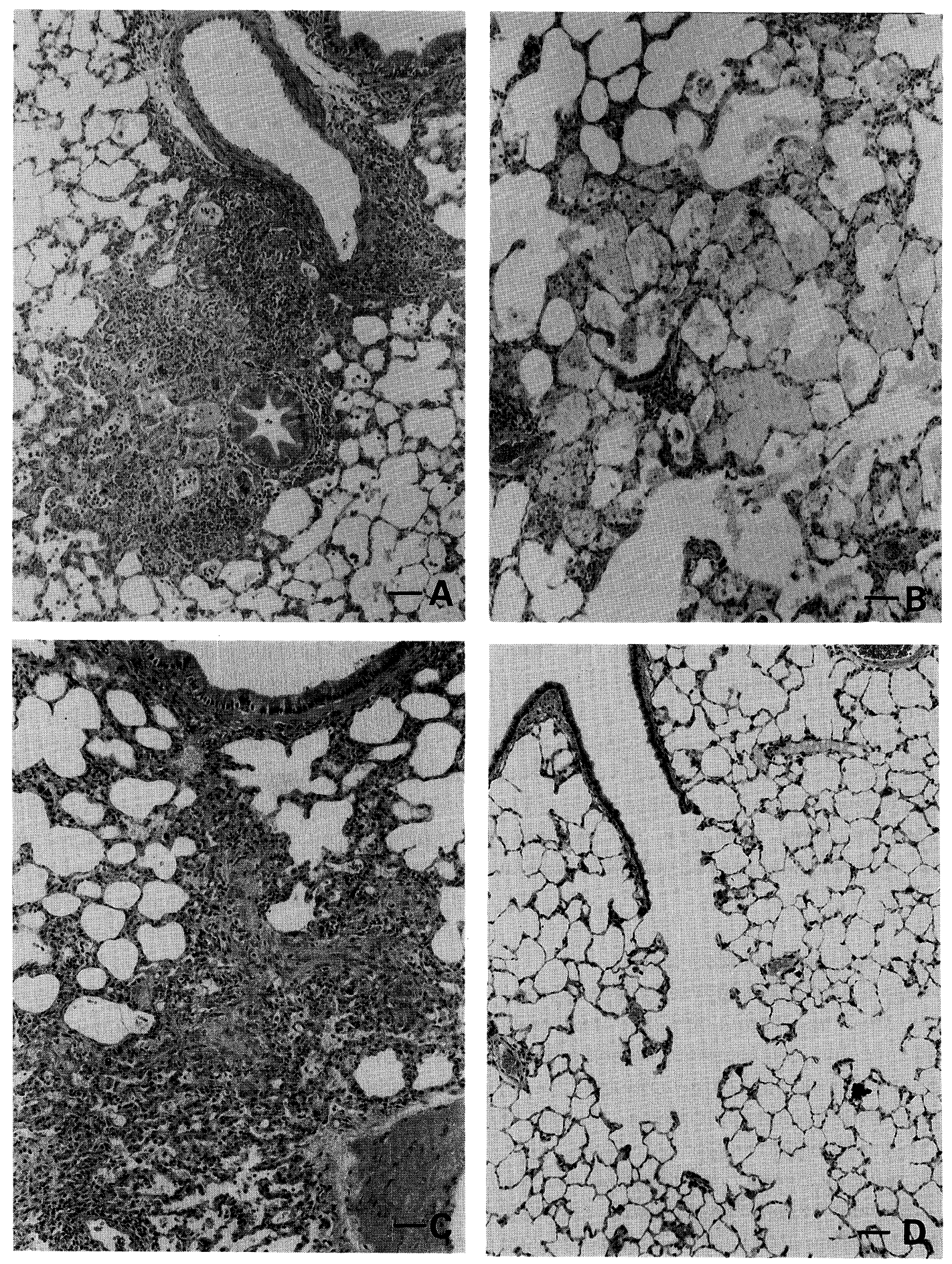

Fig. 3. In A, goblet cell hyperplasia, and perivascular inflammatory cells and edema in the alveolar space in the rat lung on Day 4 after a single instillation of $14.3 \mathrm{mg}$ nickel fumes $/ \mathrm{kg}$ b.w. In B, exudate of proteinaceous materials in the alveolar space on Day 7 after the 4th instillation of $5.9 \mathrm{mg}$ nickel fumes $/ \mathrm{kg}$. In C, goblet cell hyperplasia, inflammatory cells in the alveolar space, and thickening of the alveolar wall and minimal fibrous reaction cells on Day 7 after a single instillation of $1.4 \mathrm{mg} \mathrm{Ni} \mathrm{O}_{3} / \mathrm{kg}$. In $\mathrm{D}$, no apparent change in the lungs on Day 7 after a single instillation of $13.0 \mathrm{mg} \mathrm{NiO} / \mathrm{kg}$

All staining by $\mathrm{H} \& \mathrm{E}$, magnification at $\times 33.3$ and the bars $=50 \mu \mathrm{m}$. 
Table 3. Lung lesions induced by intratracheal instillation of nickel fumes into Sprague-Dawley rats

\begin{tabular}{clcccc}
\hline \multirow{3}{*}{ Site } & Intratracheal instillation & \multicolumn{2}{c}{ Single } & \multicolumn{2}{c}{ Repeated } \\
& Dose/body weight & \multicolumn{2}{c}{$14.3 \mathrm{mg} / \mathrm{kg}$} & \multicolumn{2}{c}{$5.9 \mathrm{mg} / \mathrm{kg}$} \\
& Type of lesion & $4 \mathrm{~d}-1 \mathrm{wk}$ & $4 \mathrm{wk}-8 \mathrm{wk}$ & $4 \mathrm{~d}-1 \mathrm{wk}$ & $4 \mathrm{wk}-8 \mathrm{wk}$ \\
\hline \multirow{5}{*}{ Bronchus } & Degeneration & $0-1$ & 0 & $0-1$ & 0 \\
& Desquamation/Regeneration & $0-1 / 0$ & $0 / 0$ & $0 / 0$ & $0 / 0$ \\
& Reactive hyperplasia & 1 & 0 & 0 & 0 \\
& Inflammation & $1-2$ & 1 & 1 & 1 \\
\hline \multirow{5}{*}{ Bronchiole } & Degeneration & $0-1$ & 0 & 0 & 0 \\
Alveolar duct & Desquamation/Regeneration & $0-1 / 0$ & $0 / 0$ & $0-1 / 0-1$ & $0 / 0$ \\
& Reactive hyperplasia & 2 & $0-1$ & 0 & 0 \\
& Fibrosis of Alv.duct & 0 & 0 & $1-2$ & $1-2$ \\
& Inflammation & $1-2$ & 0 & 2 & 2 \\
\hline \multirow{5}{*}{ Alveolus } & Mobilization/Destruction of M $\Phi$ & $4 / 4$ & $2 / 2$ & $3 / 3$ & $3 / 4$ \\
& Increase/Destruction of Foamy cells & $2 / 2$ & $3 / 2$ & $3 / 3$ & $4 / 4$ \\
& Reactive hyperplasia & 2 & 0 & 0 & 0 \\
& Granuloma/Fibrosis & $1-3 / 1$ & $1 / 0$ & $2 / 1$ & $2 / 0-1$ \\
& Thickening/Fibrosis of Alv.wall & $2-3 / 1$ & $2-3 / 2$ & $4 / 1-2$ & $4 / 2$ \\
& Edema & $2-4$ & $1-2$ & 3 & 3 \\
& Proteinosis & 0 & 0 & $2-3$ & 3 \\
\hline
\end{tabular}

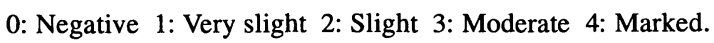

Table 4. Lung lesions induced by intratracheal instillation of $\mathrm{Ni}_{2} \mathrm{O}_{3}$ and $\mathrm{NiO}$ power into Sprague-Dawley rats

\begin{tabular}{|c|c|c|c|c|}
\hline \multirow{3}{*}{ Site } & \multirow{3}{*}{$\begin{array}{l}\text { Intratracheal instillation } \\
\text { Dose/body weight } \\
\text { Type of lesion }\end{array}$} & \multicolumn{2}{|c|}{$\mathrm{Ni}_{2} \mathrm{O}_{3}$} & \multirow{3}{*}{$\begin{array}{c}\mathrm{NiO} \\
13.0 \mathrm{mg} / \mathrm{kg} \\
4 \mathrm{wk}\end{array}$} \\
\hline & & $13.0 \mathrm{mg} / \mathrm{kg}$ & $1.4 \mathrm{mg} / \mathrm{kg}$ & \\
\hline & & $1 \mathrm{wk}$ & $4 \mathrm{wk}$ & \\
\hline \multirow{4}{*}{ Bronchus } & Degeneration & 4 & 0 & 0 \\
\hline & Desquamation/Regeneration & $2 / 2$ & $0 / 0$ & $0 / 0$ \\
\hline & Hyperplasia & 3 & 0 & 0 \\
\hline & Inflammation & 2 & 0 & 0 \\
\hline \multirow{3}{*}{$\begin{array}{l}\text { Bronchiole } \\
\text { and }\end{array}$} & Degeneration & 2 & 0 & 0 \\
\hline & Desquamation/Regeneration & $2 / 3$ & 0 & 0 \\
\hline & Hyperplasia & 3 & 0 & 0 \\
\hline \multirow[t]{2}{*}{ Alveolar duct } & Fibrosis of Alv.duct & 1 & 2 & 0 \\
\hline & Inflammation & 2 & 0 & 0 \\
\hline \multirow{7}{*}{ Alveolus } & Mobilization/Destruction of $\mathbf{M} \Phi$ & $3 / 3$ & $2 / 0-1$ & $1 / 0$ \\
\hline & Increase/Destruction of Foamy cells & $2 / 2$ & $2 / 1-2$ & $0 / 0$ \\
\hline & Hyperplasia & 2 & 0 & 0 \\
\hline & Granuloma/Fibrosis & $3 / 1$ & $2-3 / 1$ & $0 / 0$ \\
\hline & Thickening/Fibrosis of Alv.wall & $2 / 1$ & $1 / 0-1$ & $0 / 0$ \\
\hline & Edema & 3 & 0 & 0 \\
\hline & Proteinosis & 0 & 1 & 0 \\
\hline
\end{tabular}

0: Negative 1: Very slight 2: Slight 3: Moderate 4: Marked. 


\section{Discussion}

In the present study comparison of the lung toxicity of nickel fumes and their principal oxidized components, $\mathrm{Ni}_{2} \mathrm{O}_{3}$ and $\mathrm{NiO}$ powders, was made in terms of growth rate, gross findings in the tissues and histopathological examination of the lungs. The administration of $\mathrm{Ni}_{2} \mathrm{O}_{3}$ powder produced the least gain in body weight and the severest changes in the lungs as detected by both gross and histopathological observations, followed by nickel fumes. However, the NiO powder produced neither any significant pathological change nor growth rate change.

The histopathological changes resulting from the single instillation of $14.3 \mathrm{mg}$ nickel fumes/ $\mathrm{kg}$ were milder than those induced by $13.0 \mathrm{mg} \mathrm{Ni}_{2} \mathrm{O}_{3} / \mathrm{kg}$ but severer than those induced by a single instillation of $1.4 \mathrm{mg} \mathrm{Ni}_{2} \mathrm{O}_{3} / \mathrm{kg}$. In sharp contrast to the significant histopathological changes in the lungs induced by both nickel fumes and $\mathrm{Ni}_{2} \mathrm{O}_{3}$ powder, a single instillation of $\mathrm{NiO}$ powder did not produce any detectable effects on the lungs at least up to 8 weeks. The present findings on the absence of acute and subchronic effects of $\mathrm{NiO}$ are consistent with the results reported by Wehner et al. ${ }^{5)}$ and Dunnick et al. ${ }^{12)}$ who demonstrated no significant histopathological changes in the lung after exposure of hamsters, rats and mice to the inhalation of $\mathrm{NiO}$ particles. It can therefore be inferred that acute or subacute lung toxicity resulting from exposure to nickel fumes is mediated primarily through the $\mathrm{Ni}_{2} \mathrm{O}_{3}$ component in the nickel fumes rather than $\mathrm{NiO}$.

In the present study, it was found by polarographic analysis that the nickel fumes generated from the plasma flame metal sprayer were chemically composed of two oxidized forms: $1.2-3.2 \%$ of $\mathrm{Ni}_{2} \mathrm{O}_{3}$ and $98.8-96.8 \%$ of $\mathrm{NiO}$. Assuming 3\% to be the $\mathrm{Ni}_{2} \mathrm{O}_{3}$ content in nickel fumes, the two oxidized forms of $\mathrm{Ni}_{2} \mathrm{O}_{3}$ and $\mathrm{NiO}$ in the $14.3 \mathrm{mg}$ nickel fumes $/ \mathrm{kg}$ administration can be estimated to be composed of $0.43 \mathrm{mg}$ $\mathrm{Ni}_{2} \mathrm{O}_{3} / \mathrm{kg}$ and $13.9 \mathrm{mg} \mathrm{NiO} / \mathrm{kg}$, respectively. On the basis of the present histopathological findings, it can be noted that the lung toxicity induced by the single instillation of $14.3 \mathrm{mg}$ nickel fumes $/ \mathrm{kg}$, which is estimated to contain 0.43 $\mathrm{mg} \mathrm{Ni} \mathrm{O}_{3} / \mathrm{kg}$, was severer than that induced by the $1.4 \mathrm{mg}$ $\mathrm{Ni}_{2} \mathrm{O}_{3} / \mathrm{kg}$ administration. This means that, in addition to the $\mathrm{Ni}_{2} \mathrm{O}_{3}$ component, another factor may be involved in the lung pathogenesis of nickel fume toxicity. It was found by TEM observation that the size distribution of $\mathrm{Ni}_{2} \mathrm{O}_{3}$ powder was similar to that of the fine particles in nickel fumes and that there was a great difference between the size distribution of $\mathrm{Ni}_{2} \mathrm{O}_{3}$ powder detected in the present TEM observation
$(0.42 \pm 2.0 \mu \mathrm{m})$ and the nominal size $(2.0 \pm 1.69 \mu \mathrm{m})$ according to the manufacturer. Nevertheless, the possibility that the size distribution of $\mathrm{Ni}_{2} \mathrm{O}_{3}$ determined by the TEM observation may not reflect the real size distribution of the powder in the aqueous solution cannot be ruled out. It can therefore be inferred on the basis of the study by Oberdöester et al. ${ }^{19)}$ that the ultrafine particle size as well as the active component of $\mathrm{Ni}_{2} \mathrm{O}_{3}$ in nickel fumes plays an important role in nickel fumes-induced lung lesions, because the ultrafine particles were agglomerated in nickel fumes. One plausible explanation for the enhanced lung toxicity is that the surface area which interacts with surrounding biomolecules would be much larger for nickel fumes than for $\mathrm{NiO}$ powder.

The present study demonstrated that solubility of the three particulates in physiological saline was in the order of nickel fumes $>\mathrm{Ni}_{2} \mathrm{O}_{3} \gg>\mathrm{NiO}$. The greater solubility of nickel fumes and $\mathrm{Ni}_{2} \mathrm{O}_{3}$ powder in saline is presumed to be attributable to the larger surface area of nickel fumes and $\mathrm{Ni}_{2} \mathrm{O}_{3}$ powder, both of which were composed of abundant ultrafine particles. The mechanism by which nickel fumes adversely affect the lung remains unclear, but it can be surmised that the acute and subacute lung toxicity induced by nickel fumes is mediated at least through both very toxic $\mathrm{Ni}_{2} \mathrm{O}_{3}$ and ultrafine particles. Sawatari ${ }^{20)}$ reported that reactive oxygen and hydroxy radicals were generated during the process of conversion of $\mathrm{Ni}(\mathrm{III})$ to $\mathrm{Ni}(\mathrm{II})$ ions, when $\mathrm{Ni}_{2} \mathrm{O}_{3}$ powders were dissolved in an aqueous solution. Kawanishi et al. ${ }^{21)}$ suggested that the production of these reactive oxygen and hydroxy radicals in the presence of $\mathrm{Ni}(\mathrm{II})$ and $\mathrm{H}_{2} \mathrm{O}_{2}$ damaged biomolecular components such as DNA. It is therefore tempting to speculate that the epithelial injury induced by the reactive species of oxygen and hydroxy radicals, which would be produced by both the process of conversion of $\mathrm{Ni}(\mathrm{III})$ and the phagocytosis of nickel fumes, is involved in the pathogenesis of nickel fumes-induced lung lesions. Further study will be clarify the effects of very fine nickel fumes on phagocytic activity.

\section{Acknowledgments}

The authors are grateful to Drs. Heihachiro Arito, Hiroko Kyono and Norihiko Kohyama for their critical reviews of the manuscript and encouragement in the present study.

\section{References}

1) National Research Council (1975) Nickel. In: Medical and biologic effects of environmental pollutants. 11, 
National Academy of Sciences, Washington, D.C.

2) Camner P, Casarett-Bruce M, Curstedt T, Jarstrand $C$, Wiernik A, Johansson A, Lundborg M, Robertson B (1984) Toxicology of nickel. In: Nickel in the human environment. IARC Scientific Publications No. 53. eds. by Sunderman FW et al. 267-76, Lyon.

3) McConnell LH, Fink JN, Schlueter DP, Schmidt Jr MG (1973) Asthma caused by nickel sensitivity. Ann Intem Med 78, 888-90.

4) Jones JG, Warner CG (1972) Chronic exposure to iron oxide, chromium oxide, and nickel oxide fumes of metal dressers in a steelworks. Brit J Ind Med 29, 169-77.

5) Wehner AP, Busch RH, Olson RJ, Craig DK (1975) Chronic inhalation of nickeloxide and cigarette smoke by hamsters. Am Ind Hyg Assoc J 36, 801-10.

6) International Agency for Research on Cancer (1990) IARC monographs on the evaluation of the carcinogenic risk of chemicals to humans, vol. 49, nickel and nickel compounds. 410-1, Lyon.

7) DHHS (1988) (NIOSH) publication No.88-110. Criteria for a recommended standard: Welding, Brazing, and Thermal Cutting. 57-135, NIOSH Publications, Cincinnati.

8) Beckett WS (1996) Welding. In: Occupational and environmental respiratory disease. eds. by Harber $P$, Schenker MS, Balmes JR, 710, Mosby Publication.

9) Johansson A, Lundborg M, Hellstrom PA, Camner P, Keyser TR, Kirton SE, Natusch DFS (1980) Effect of iron, cobalt, and chromium dust on rabbit alveolar macrophages: A comparison with the effects of nickel dust. Environ Res 21, 165-76.

10) Johansson A, Camner P, Robertson B (1981) Effects of long-term nickel dust exposure on rabbit alveolar epithelium. Environ Res 25, 391-403.

11) Wehner AP, Moss OR, Milliman EM, Dagle GE, Schirmer RE (1979) Acute and subchronic inhalation exposures of hamsters to nickel-enriched fly ash. Environ Res 19, 355-70.

12) Dunnick JK, Benson JM, Hobbs CH, Hahn FF, Cheng
YS, Eidson AF (1988) Comparative toxicity of nickel oxide, nickel sulfate hexahydrate, and nickel subsulfide after 12 days of inhalation exposure to $\mathrm{F} 344 / \mathrm{N}$ rats and B6C3F 1 mice. Toxicology 50, 145-56.

13) Glaser U, Hochrainer D, Oldiges $H$, Takenaka $S$ (1986) Long-term inhalation studies with $\mathrm{NiO}$ and $\mathrm{As}_{2} \mathrm{O}_{3}$ aerosols in wistar rats. In: Health hazards and biological effects of welding fumes and gases. eds. by Stern RM et al. 325-8, Excerpta Medica, Amsterdam-New YorkOxford.

14) Adachi S, Katayama H, Takemoto $K$ (1989) Effect of $\mathrm{Ni}_{2} \mathrm{O}_{3}$ dust on the respiratory system. Jpn J Ind Health 31, 64-5.

15) Serita F, Homma K, Fukuda K, Sawatari K, Suzuki Y, Toya T (1990) Development of an inhalation system of high melting point metal fumes and its use for exposure of rats to chromium and nickel fumes. Ind Health 28, 185-97.

16) Serita $F$ (1983) A new technique for generating heavy metal fumes with high melting point. Ind Health 21, 67-77.

17) Homma K, Serita F, Sawatari K, Suzuki Y, Koshi K, Kyono H, Saegusa J, Fukuda K (1986) Biological effects of fumes generated from high melting metals. In: Environmental reserch in Japan, Vol II. 92-10, Environment Agency, Japan (in Japanese).

18) Litchfield JT, Wilcoxon WF (1949) A simplified method of evaluating dose-effect experiments. J Pharmacol Exp Ther 96, 99.

19) Oberdörster G, Ferin J, Gelein R, Soderholm SC, Finkelstein J (1992) Role of the alveolar macrophage in lung injury: studies with ultrafine particles. Environ Health Perspectives 97, 193-9.

20) Sawatari K (1988) Differential determination of nickel (II) oxide and nickel (III) oxide in airborne particulate substances. Ind Health 26, 115-23.

21) Kawanishi S, Inoue S, Yamamoto K (1989) Site-specific DNA damage induced by nickel (II) ion in the presence of hydrogen peroxide. Carcinogenesis 10, 2231-5. 